\title{
Penerapan PSAK No. 101 Tentang Penyajian Laporan Keuangan Syariah Pada Kopontren Al- Barkah Wonodadi Blitar
}

\author{
Anzilni Sakinah Aprilia \\ Universitas Islam Negeri Sayyid Ali RabmatullabTulungagung \\ anzilnisakinahaprilia@gmail.com \\ Dyah Pravitasari \\ Universitas Islam Negeri Sayyid Ali RabmatullabTulungagung \\ dyahpravitasariiainta@gmail.com
}

\begin{abstract}
Naturally, any financial institution guided by sharia principles will present its financial statements in accordance with PSAK No. 101. The purpose of this study was to evaluate the financial statements presented at Al-Barkah Islamic Boarding School Cooperative using PSAK 101. The qualitative descriptive research method was used in this study. The data was gathered using techniques such as observation, interviewing, documenting, and conducting literature research. The findings concluded that Al-Barkah Islamic Boarding School Cooperative presented a statement of financial position and income statement, but did not fully implement PSAK 101 due to the absence of five additional reports and the inadequacy of several components of the two that were presented. The reason for this is that the Al-Barkah Islamic Boarding School Cooperative only provides two types of financial statements: the statement of financial position and the income statement. The two reports presented are deemed to have satisfied the Al-BarkahKopontren's information requirements. However, as time passes, Kopontren Al-Barkah continues to improve the quality of existing experts and to leverage technology to aid in the presentation of financial statements in accordance with established standards.
\end{abstract}

Keywords: Kopontren, Financial Statement, PSAK No. 101

\begin{abstract}
Abstrak. Setiap lembaga keuangan yang berpedoman pada prinsip syariah tentunya berlandaskan pada PSAK No. 101 dalam penyajiian laporan keuangannya. Tujuan dilakukannya penelitian ini adalah untuk mengetahui kesesuaian laporan keuangan yang tersaji pada Koperasi Pondok Pesantren Al- Barkah dengan PSAK 101. Dalam penelitian ini digunakan metode penelitian deskriptif kualitatif. Data yang dikumpulkan didapatkan melalui teknik pengumpulan data berdasarkan observasi, wawancara, dokumentasi dan penelitian kepustakaan. Hasilnya disimpulkan bahwa Koperasi Pondok Pesantren Al- Barkah telah menyajikan laporan posisi keuangan dan laporan laba rugi, namun belum menerapkan PSAK 101 secara menyeluruh karena terdapat lima laporan lain yang belum disajikan serta terdapat beberapa komponen yang belum lengkap pada dua laporan yang telah disajikan. Penyebab hanya disajikan dua jenis laporan keuangan oleh Koperasi Pondok Pesantren Al- Barkah yaitu karena menurut pihaknya hanya membutuhkan dua laporan keuangan saja yakni laporan posisi keuangan dan laporan laba rugi. Dua laporan yang telah tersaji dianggap sudah memenuhi kebutuhan informasi pada Kopontren Al- Barkah. Namun, seiring berjalannya waktu Kopontren Al- Barkah juga terus meningkatkan kualitas terhadap tenaga ahli yang ada serta terus memanfaatkan ilmu teknologi dalam membantu penyajian laporan keuangan yang sesuai dengan pedoman yang ada.
\end{abstract}

Kata kunci: Kopontren, Laporan Keuangan, PSAK No. 101
Received: October 25, 2021 1st Revision: December 15, 2021 Published: January 11, 2022

Diterima:

25 Oktober 2021

Direvisi:

15 Desember 2021

Dipublikasi:

11 Januari 2022 


\section{PENDAHULUAN}

Pada dasarnya ekonomi islam adalah ekonomi yang berdasar terhadap moral dan akhlak mulia yang tinggi sehingga semua kegiatan dan aktivitas yang dilakukan manusia tidak akan keluar dari ajaran baik al-quran dan hadits (Aedy, 2007). Ekonomi dan keuangan menjadi hal yang penting ditengah- tengah masyarakat saat ini. Perkembangannya akan selalu diikuti dengan meningkatnya berbagai aktivitas ekonomi yang tentunya diiringi juga dengan masyarakat yang semakin membutuhkan modal atau uang dalam bentuk tunai. Hal tersebut yang memunculkan adanya lembaga keuangan seperti Koperasi Pondok Pesantren (Kopontren) Al-Barkah. Sebagai koperasi syariah, koperasi Pondok pesantren Al- Barkah menjalankan aktivitas usahanya dengan berpedoman pada sistem syariah yang sudah diatur pada Akuntansi Keuangan Syariah.

Panduan penerapan tentang akuntansi syariah telah diatur dalam perundang - undangan. Di Indonesia, perkembangan Akuntansi Syariah diawali dengan disahkannya PSAK 59 tanggal 1 Mei 2002 mengenai Akuntansi Perbankan Syariah dan sejak tanggal 1 Januari 2003 mulai berlaku pernyataan ini. Koperasi Pondok Pesantren Al-Barkah, dalam menjalankan usahanya tentunya akan membuat laporan keuangan. Hal tersebut diperlukan untuk menyajikan kondisi mengenai posisi serta perubahan keuangan suatu entitas terhadap pihak- pihak yang berkepentingan. Karena hal tersebutlah, penyajian serta pelaporan laporan keuangan entitas dengan berpedoman pada sistem syariah wajib berdasarkan pada Standar Akuntansi Keuangan Syariah yang ada salah satunya adalah PSAK 101, dimana pernyataan ini memuat persyaratan pencatatan serta penyajian laporan keuangan institusi syariah. Pada pernyataan ini dijabarkan mengenai struktur serta komponen isi yang harus ada dalam laporan keuangan syari'ah yaitu: 1) Laporan posisi keuangan; 2) Laporan perubahan ekuitas; 3) Laporan laba rugi; 4) Laporan arus kas; 5) Laporan sumber dan penggunan dana kebajikan; 6)Laporan sumber dan penggunaan zakat; 7) Catatan atas laporan keuangan.

Pengelolaan keuangan yang berbasis syariah akan tercapai bila standar akuntansi syariah pada suatu entitas diterapkan dengan baik (Desita, 2006). Fokus penelitian ini penulis pusatkan terhadap Pernyataan Standar Akuntansi Keuangan (PSAK) No. 101 mengenai penyajian laporan keuangan syariah. Laporan keuangan yang dibuat entitas haruslah dikawal agar tidak ditemukan penyimpangan terhadap sistem yang ada (Asmitha, 2011). Beberapa pertanyaan yang muncul yang dapat dijawab yaitu sebagai Koperasi yang berpedoman pada sistem syariah, apakah Koperasi Pondok Pesantren Al-Barkah telah mengacu dan menerapkan standar akuntansi syariah yang berlaku dalam penyajian laporan keuangannya, sedangkan pada kenyataannya standar akuntansi syariah yang diterapkan kerap kali masih terkendala oleh sedikitnya tenaga ahli yang benar- benar menguasai dan berkompeten dalam akuntansi keuangan syariah, prinsip- prinsip syariah termasuk prinsip bagi hasil yang membutuhkan kejujuran serta sistem pengawasan yang belum terlaksana secara maksimal. 
Penulis memilih untuk mengkaji Koperasi Pondok Pesantren Al - Barkah ini yang terletak di JL. Soekarno Hatta No. 29 Wonodadi Blitar sebagai objek penelitian, lantaran dalam operasionalnya, Koperasi Pondok Pesantren Al- Barkah yang merupakan jenis koperasi syariah ini sudah cukup lama berdiri tetapi jika dilihat dari Laporan Keuangan yang dibuat masih belum menunjukkan kesesuaian dengan PSAK 101. Hal ini tentunya bertentangan dengan prinsip PSAK 101, sehingga masih harus banyak diperbaiki dan disesuaikan dengan aturan yang tertera dalam PSAK 101. Penerapan yang sesuai merupakan hal yang sangat penting, mengingat menjalankan sebuah usaha syariah merupakan tanggung jawab yang besar. Bagi pihak internal koperasi, laporan keuangan yang tidak sesuai dengan standar yang berlaku, dalam hal ini yaitu PSAK 101 akan menyebabkan sulitnya pengevaluasian serta pengambilan kebijakan mengenai apa saja yang dapat dilakukan perusahaan di masa yang akan datang. Selain itu, kemungkinan kebocoran aset dan kecurangan lebih besar terjadi saat laporan keuangan tidak tersaji secara lengkap. Bagi pihak eksternal, untuk melihat performa suatu perusahaan diperlukan laporan keuangan yang lengkap. Untuk kreditur penilaian kemampuan perusahaan dalam mengembalikan pinjaman didapat dari laporan keuangan, lalu pemungutan pajak juga membutuhkan laporan keuangan, selanjutnya yaitu para investor menggunakan laporan keuangan suatu perusahaan sebagai pertimbangan dalam menanamkan modalnya. Hal lainnya yakni lewat informasi dari laporan keuangan, masyarakat dapat menilik kontribusi dan kredibilitas perusahaan yang bisa dijadikan pertimbangan untuk menabung, meminjam, ataupun dalam melamar kerja.

Prinsip keuangan Syariah yang ada berdasarkan konsep, teori, dan pendapat para ahli semuanya mengacu kepada prinsip rela sama rela, tidak ada pihak yang menzalimi dan dizalimi , hasil usaha muncul bersama biaya, dan untung muncul bersama risiko (Nurhayati \& Wasilah, 2019). Tujuan dan landasan tersebut diharapkan mampu mengarahkan penyusunan standar akuntansi dan pelaporan keuangan yang konsisten serta memiliki arah, fungsi, dan batasan yang jelas. Sehingga, hasil dari penelitian ini nantinya diharapkan dapat membantu Koperasi Pondok Pesantren $\mathrm{Al}$ - Barkah dalam memperbaiki laporan keuangannya sesuai dengan standart yang tertera dalam PSAK 101. Menurut keadaan yang telah disebutkan diatas, maka penulis akan meneliti Penerapan PSAK No.101 tentang Penyajian Laporan Keuangan Syariah pada Kopontren Al- Barkah Wonodadi Blitar. 


\section{KAJIAN LITERATUR}

\section{Akuntansi}

Akuntansi merupakan suatu kegiatan mencatat, menggolongkan, menyortir dan menyajikan transaksi keuangan dari suatu entitas yang berguna untuk pihak- pihak berkepentingan sebagai dasar pengambilan keputusan.

\section{Akuntansi Syariah}

Akuntansi syariah adalah deskonstruksi dari akuntansi secara umum menjadi tampilan yang humanis dan syarat akan nilai dengan tujuan dan fungsi akuntansi syariah sendiri yakni untuk melahirkan peradaban bisnis dengan pengetahuan yang humanis, emansipatoris, transcendental, serta teological. Dalam akuntansi syariah terdapat 3 prinsip utama yaitu keadilan, kebenaran dan pertanggungjawaban yang tentunya berdasarkan pada prinsip syariah. Tujuan akuntansi syariah dapat diuraikan sebagai berikut (Kusumawati, 2005)

1. Melindungi harta suatu entitas syariah (Hifzul Maal)

Ini berarti akuntansi syariah memiliki tujuan untuk menjaga harta, menghindari serta menghilangkan rasa keraguan saat semua transaksi yang terjadi dicatat dan dilaporkan sesuai dengan pedoman akuntansi syariah yang berlaku.

2. Pencatatan Meminimalisir Perselisihan

Ketika suatu entitas melakukan pencatatan pada setiap aktivitas dan transaksi keuangan yang terjadi, maka hal tersebut nantinya dapat berguna untuk memberikan kesaksian yang nyata dan kuat jika dikemudian hari terjadi perselisihan terhadap harta yang dimiliki.

3. Dasar Pengambilan Keputusan

Keputusan dapat diambil hanya setelah mengetahui data perusahaan yang mencakup informasi keadaan keuangan suatu entitas, maka keberadaan pencatatan transaksi akan memudahkan pihak internal atau manajemen untuk mengambil langkah apa yang harus dilakukan entitas untuk meningkatkan kinerja perusahaannya.

4. Penghitungan Hak- Hak Berserikat

Pada aktivitasnya entitas tentunya terdapat akad dengan jenis perserikatan dengan pihak lain. Penghitungan hak- hak dan modal akan lebih mudah jika pencatatan dilakukan dengan baik.

5. Penentuan Zakat yang Dikeluarkan

Saat akan menentukan zakat yang akan dikeluarkan, sebuah entitas sebelumnya tentunya harus mengetahui total hasil yang diperoleh. Dasar pencatatan keuangan yang baik akan memudahkan entitas untuk melakukan perhitungan jumlah zakat yang harus dikeluarkan atas harta yang dimiliki. 
6. Penentuan Pemberian Imbalan, Sanksi, Dan Balasan

Akuntansi syariah tentunya harus mempresentasikan akuntansi berdasarkan dengan tujuan dari aktivitas transaksi tersebut yaitu dijadikan penentuan imbalan, sanksi, dan balasan.

\section{Laporan Keuangan}

Tujuan dari penerapan akuntansi itu sendiri adalah laporan keuangan. Laporan keuangan ialah sebuah catatan informasi atas semua transaksi dan aktivitas yang telah dilakukan yang berisi keadaan serta perubahan posisi keuangan suatu perusahaan. Setiap entitas tentunya wajib melakukan pencatatan serta penyajian laporan keuangan sebagai pertanggung-jawaban atas segala aktivitas keuangan yang dilakukan.

\section{Pernyataan Standar Akuntansi Keuangan (PSAK) 101}

Pernyataan Standar Akuntansi Keuangan 101: Laporan keuangan syariah atau yang sering disingkat dengan PSAK 101 mencantumkan tujuan serta dasar laporan keuangan yang tersaji bagi suatu institusi syariah. Panduan mengenai penyajian, struktur, serta persyaratan minimal isi laporan keuangan pada perusahaan syariah sehubungan aktivitas dan transaksi yang dilakukan telah diuraikan dalam pernyataan ini (Ikatan Akuntan Indonesia, 2009).

1. Sejarah dan Perkembangan Pernyataan Standar Akuntansi Keuangan 101

Setiap perusahaan yang menyajikan laporan keuangan mengandung tujuan agar dapat mengetahui apa yang terjadi pada perusahaannya.PSAK 101 dicetuskan dan disahkan Dewan Standar Akuntansi Keuangan Ikatan Akuntan Indonesia (DSAK IAI) pertama kali tanggal 27 Juni 2007. Panduan ini dikeluarkan untuk mengganti pedoman penyajian laporan keuangan institusi syariah yang sebelumnya diatur pada PSAK 59: Akuntansi Perbankan Syariah yang muncul tanggal 1 Mei 2002. Pedoman Standar Akuntansi Syariah menjadi krusial serta pondasi untuk keberhasilan suatu lembaga keuangan syariah untuk memberikan pelayanan kepada masyarakat luas, informasi yang disajikan oleh bank harus relatif akurat, dapat dipertanggungjawabkan, serta relevan untuk pemakainya, tapi masih dalam konteks syariah islam. Dewan Pengurus Nasional (DPN) IAI mengeluarkan surat dengan No. 0823B/DPN/IAI/X1/2013, berdasarkan surat tersebut otomatis kewenangan atas semua yang berkaitan dengan akuntansi syariah yang semula diterbitkan DSAK IAI diambil alih oleh Dewan Standar Akuntansi Syariah Ikatan Akuntan Indonesia (DSAS IAI), Sesudah disahkan pada awal 2007, PSAK 101 melewati perubahan serta revisi mengenai beberapa hal antara lain:

a. Akibat direvisinya PSAK 1 mengenai Penyajian Laporan Keuangan pada tanggal 16 Desember 2011

b. Akibat direvisinya PSAK 1 yang berisi Penyajian Laporan Laba Rugi dan Penghasilan Komprehensif Lainnya pada tanggal 15 Oktober 2014 
c. Dan revisi selanjutnya mengenai penyajian laporan keuangan entitas asuransi syariah. Ini akibat dari direvisinya PSAK 108 mengenai Akuntansi Transaksi Syariah, kemudian mulai diterapkan pada tanggal 1 Januari 2017.

2. Ketentuan Penyajian Laporan Keuangan Syariah Berdasarkan PSAK 101

Seluruh lembaga keuangan yang menjalankan aktivitasnya menggunakan prinsip Syariah mempunyai pedoman serta aturan khusus yang berbeda satu sama lainnya. Terdapat perbedaan pada lembaga keuangan yang berpedoman pada prinsip syariah yaitu dapat menjalankan aktivitas dan kegiatannya yang relatif memiliki persamaan sebab pemakaian instrumen akad yang sama mengacu pada prinsip Syariah. Pada PSAK 101 telah diuraikan mengenai persyaratan umum yang ada dalam laporan keuangan organisasi Syariah, persyaratan dan muatan tersebut mencakup: penyajian wajar serta kepatuhan pada Standar Akuntansi Keuangan, dasar akrual, materialistis serta penggabungan, saling hapus, frekuensi pelaporan, informasi komparatif dan yang terakhir konsistensi penyajian laporan keuangan. Ketentuan akuntansi syariah untuk entitas syariah dimuat pada PSAK 101 sampai dengan 107. PSAK tersebut dijadikan pedoman secara komprehensif untuk semua entitas syariah dalam melakukan aktivitas dan transaksi. Tetapi di lain sisi ada PSAK yang hanya digunakan untuk industri khusus, sebab mempunyai aspek khusus yang tidak bisa disamaratakan dengan entitas lain (Dewan Standar Akuntansi Syariah - IAI, 2016). Pernyataan ini telah menguraikan penjelasan mengenai struktur dan komponen isi pada laporan keuangan Syariah yang meliputi beberapa hal seperti:

a. Laporan Posisi Keuangan

Laporan posisi keuangan atau neraca berisi informasi yang memuat keadaan keuangan suatu entitas terkait dengan keadaan keuangan, likuiditas, solvabilitas dan keberhasilan entitas menyesuaikan dengan lingkungan yang berubah- ubah (Sri Nurhayati, 2011). Laporan posisi keuangan yang tersaji pada suatu entitas syariah minimal memiliki cakupan komponen sebagai berikut: kas dan setara kas, piutang usaha beserta piutang lainnya, persediaan, investasi dengan metode ekuitas, aset keuangan, total aset, properti'investasi, aset tetap, aset tidak berwujud, kewajiban usaha maupun terutang lainnya, kewajiban keuangan, liabilitas dan aset untuk pajak kini, liabilitas dan aset pajak tangguhan, kewajiban yang termasuk didalam kelompok lepasan milik untuk dijual, provisi, kepentingan non pengendali, serta modal saham dan cadangan yang diatribusikan kepada pemilik entitas induk.

Laporan ini tersaji sebagai neraca. Laporan posisi keuangan berfungsi sebagai alat prediksi kemampuan entitas pada masa depan. Informasi yang tersaji pada laporan ini yaitu sebagai berikut:(Ikatan Akuntan Indonesia, 2009) 
1) Informasi pertama yang termuat dalam laporan posisi keuangan merupakan aset. Aset berarti segala sesuatu yang dikuasai oleh entitas yang didapatkan dari penghasilan atau pendapatan dari transaksi dan aktivitas lain yang dilakukan entitas di masa lampau.

2) Informasi selanjutnya yaitu mengenai kewajiban atau liabilitas suatu entitas. Kewajiban atau liabilitas ialah seluruh pengorbanan yang dibuat entitas untuk mendapatkan atau memperoleh sesuatu di masa depan dan memberikan ganti berupa penyerahan aset ataupun jasa untuk entitas lain sebagai ganti atas transaksi atau perjanjian yang telah dilakukan.

3) Informasi ketiga yaitu Dana Syirkah Temporer. Dana ini diperoleh dari sesorang atau sumber lainnya untuk digunakan sebagai investasi dengan kurun waktu yang telah disepakati. Entitas syariah selanjutnya bisa mengolah dana yang didapatkan serta menjalankan bagi hasil sesuai kesepakatan antar kedua belah pihak. Dana syirkah temporer tidak tergolong dalam kewajiban sebab saat mengalami kerugian, entitas syariah tidak wajib mengembalikan dana kecuali jika disebabkan oleh kelalaian entitas syariah itu sendiri. Tetapi, dana syirkah temporer ini juga tidak tergolong sebagai ekuitas. Hal tersebut dikarenakan dana ini memiliki kurun waktu hak kepemilikan tidak dimiliki sama seperti pada pemegang saham.

4) Informasi terakhir yang termuat pada laporan posisi keuangan adalah Ekuitas. Ekuitas merupakan suatu sumber daya yang dimiliki dalam aset yang masih tersisa sesudah dikurangi oleh liabilitas serta dana syirkah temporer.

\section{b. Laporan Laba Rugi dan Penghasilan Komprehensif Lain}

Laporan laba rugi ialah penggambaran dalam bentuk sajian kinerja maupun aktivitas pada suatu periode yang memuat penghasilan serta beban yang muncul akibat aktivitas primer serta aktivitas operasi lainnya pada entitas syariah (Muljono, 2015). Dalam suatu periode laporan keuangan tertentu seluruh pos penghasilan ataupun beban diakui jika memuat aspek laba rugi serta aspek komprehensif lainnya. Laporan ini memuat komponen- komponen yang tersaji kedalam pos- pos sebagai berikut yaitu: penghasilan yang diperoleh, kemudian bagi hasil yang ditujukan untuk pemilik modal/dana, laba rugi dari entitas asosiasi social serta ventura bersama yang telah dicatat dengan metode ekuitas, beban pajak, dan yang terakhir jumlah tunggal bagi operasi yang dihentikan (Ikatan Akuntan Indonesia, 2009)

c. Laporan Perubahan Ekuitas

Hal ini berisi informasi mengenai penambahan maupun pengurangan suatu ekuitas yang dikuasai oleh entitas syariah yang memuat gambaran kenaikan dan penurunan kekayaan atau aktiva bersih entitas syariah (Muljono, 2015). Pos- pos tersebut tersaji dalam laporan 
perubahan ekuitas yang mencakup: jumlah penghasilan komprehensif pada suatu periode, dampak penerapan retrospektif atau penyajian kembali setiap komponen ekuitas yang telah diakui, rekonsiliasi atas setiap unsur ekuitas, secara terpisah menyajikan perubahan laba rugi, pendapatan komprehensif lain serta transaksi pemilik dalam kemampuannya sebagai pemilik (Ikatan Akuntan Indonesia, 2009).

d. Laporan Arus Kas

Dapat diartikan sebagai laporan yang berisikan kegiatan sehubungan dengan kas masuk maupun kas keluar entitas yang terjadi selama periode tertentu. Didalamnya memuat beberapa pos- pos antara lain: sumber dan penggunaan kas operasional, investasi, serta pendanaan (Muljono, 2015).

e. Laporan Sumber dan Penggunaan Dana Zakat

Pos- pos yang dimuat pada laporan ini mencakup: dana zakat yang berasal dari wajib zakat pada entitas syariah maupun luar entitas syariah, penyaluran dana zakat melalui entitas pengelola zakat, penurunan maupun kenaikan dana zakat serta saldo awal dana zakat dan saldo akhir dana zakat.

f. Laporan Sumber dan Penggunaan Dana Kebajikan

Laporan ini memuat komponen sebagai berikut: sumber dana kebajikan entitas syariah, penggunaan dana kebajikan, penurunan maupun kenaikan sumber dana kebajikan, serta saldo awal dana kebajikan dan saldo akhir dana kebajikan.

g. Catatan atas Laporan Keuangan

Informasi tambahan mengenai seluruh komponen yang telah tersaji pada bagian lain pada laporan keuangan dimuat dalam catatan atas laporan keuangan. Catatan ataslaporan keuangan ini menyajikan pos - pos antara lain: informasi umum dan kebijakan penyusunan laporan yang diterapkan suatu entitas syariah, informasi yang diungkapkan yang tidak terdapat pada SAK serta tidak tersaji dilaporan keuangan lainnya, dan yang terakhir informasi yang tidak tersaji dalam laporan keuangan (Ikatan Akuntan Indonesia, 2009).

Selanjutnya laporan keuangan yang tersaji akan digunakan sebagai perbandingan dengan laporan keuangan ditahun lalu atau dengan laporan keuangan syariah organisasi lainnya. PSAK terkait telah mengatur pengakuan, pengukuran, penyajian serta pengungkapan atas kegiatan atau aktivitas tertentu yang terjadi pada entitas syariah.

Kerangka berpikir pada penelitian ini adalah peneliti melakukan penelitian pada Koperasi Pondok Pesantren Al- Barkah dengan cara observasi, wawancara dan dokumentasi kemudian didapat Laporan Keuangan Tahunan yang selanjutnya dibandingkan dengan PSAK 101. Data yang diperoleh kemudian dianalisis untuk menarik kesimpulan kesesuaian Laporan Keuangan Koperasi Pondok Pesantren Al- Barkah dengan PSAK 101. Dan yang terakhir yaitu peneliti memberikan 
rekomendasi pada pihak Koperasi Pondok Pesantren Al- Barkah agar penyajian laporan keuangan yang dibuat sesuai dengan PSAK 101.

\section{METODE PENELITIAN}

Pendekatan kualitatif dipilih peneliti dalam penelitian ini, yang dapat diartikan penelitian yang mencermati data yang diperoleh baik berbentuk kata- kata lisan atau tulisan. Data dikumpulkan secara triangulasi, lalu analisis data dianalisis dengan pendekatan kualitatif yang akan didapat hasil penelitian lebih menegaskan arti daripada generalisasi (Sugiyono, 2016). Tujuan penelitian deskriptif kualitatif ini yaitu berguna sebagai gambaran, uraian serta jawaban secara rinci terhadap permasalahan yang diteliti dengan mempelajari semaksimal mungkin terhadap suatu individu, kelompok, atau kejadian. instrument penelitian adalah manusia dan hasil penelitian yang dihasilkan berbentuk katakata penjelasan atau pernyataan yang sesuai dengan keadaan sebenarnya di lapangan.

Data yang digunakan dalam penelitian ini, yakni berupa data primer dan data sekunder. Metode perolehan datanya, salah satunya dilakukan melalui Wawancara secara langsung dengan pihak Koperasi Pondok Pesantren Al- Barkah nantinya digunakan sebagai data primer. Data kedua yaitu data sekunder yang didapatkan dari sumber lain yaitu jurnal, buku, atau artikel serta sumber lain yang sejalan dengan penelitian ini.

Analisis data memiliki proses antara lain data- data dikumpulkan, yang dimulai dari berbagai sumber yakni berasal dari wawancara bersama informan, serta tinjauan langsung yang telah dituangkan pada catatan lapangan, hasil wawancara, serta dokumentasi, selanjutnya data yang dikumpulkan dan didapatkan melalui proses analisis. Analisis data dengan menggunakan teknik analisis deksriptif memiliki tujuan untuk mengumpulkan data dengan mereduksi data, mendisplay data serta menyimpulkan dan yang terakhir melakukan verifikasi(Ali, 2014)

\section{HASIL DAN PEMBAHASAN}

\section{Hasil}

Petunjuk dasar dalam penyajian laporan keuangan entitas syariah termasuk koperasi syariah yaitu menggunakan kerangka laporan keuangan berdasarkan PSAK 101. Sedangkan pencatatan transaksi keuangannya mengacu pada PSAK Syariah 102 sampai 110 serta transaksi yang tidak diatur dalam PSAK Syariah mengacu pada SAK ETAP. Namun, penyajian laporan keuangan yang ada pada Koperasi Pondok Pesantren Al- Barkah mengacu pada PSAK 101 tetapi hanya menerapkan 2 laporan keuangan saja (Kopontren Al- Barkah, 2020).

Koperasi Pondok Pesantren Al- Barkah yang menjalankan sistem syariah tentunya berlandaskan pada PSAK 101 dalam melakukan pencatatan dan penyajian laporan keuangannya. Berdasarkan PSAK 101 Paragraf 9, laporan keuangan entitas syariah yang lengkap terdiri atas: 1) 
Laporan Posisi Keuangan; 2) Laporan Laba Rugi;3) Laporan Arus Kas; 4) Laporan Perubahan Ekuitas; 5) Laporan Sumber dan Penggunaan Dana Zakat; 6) Laporan Sumber dan Penggunan Dana Kebajikan; serta 7) Catatan atas Laporan Keuangan (Ikatan Akuntan Indonesia, 2009).

Berdasarkan hasil dan temuan penelitian terhadap dokumen laporan keuangan Koperasi Pondok Pesantren Al- Barkah maupun wawancara dengan informan ditemukan bahwa pada Koperasi Pondok Pesantren Al- Barkah Wonodadi Blitar menunjukkan bahwa penyajian laporan keuangan syariah baru dibuat dan disajikan dalam 2 jenis saja yaitu laporan posisi keuangan dan laporan laba rugi. Namun, pelaporannya pun belum seutuhnya sama dengan aspek dan komponen yang ada pada PSAK 101. Dari wawancara dengan pihak Koperasi Pondok Pesantren Al- Barkah yang telah dilaksanakan penulis, ketidaksesuaian penyajian laporan keuangan Koperasi Pondok Pesantren Al- Barkah dengan PSAK 101 disebabkan karena pihaknya hanya membutuhkan 2 jenis laporan keuangan yakni laporan posisi keuangan dan laporan laba rugi. 2 jenis Laporan keuangan yang disajikan dan dilaporkan dirasa telah memenuhi kebutuhan informasi Koperasi Pondok pesantren Al- Barkah (Nurrafli, 2021) . Namun, hal ini sangat tidak relevan dengan prinsip PSAK 101, yang dimana kejelasan aliran dana yang terjadi dalam sebuah lembaga khususnya lembaga syariah memiliki tanggung jawab penuh terhadap nasabah, dan tanggung jawab rohani kepada Allah SWT, maka dengan demikian Koperasi Pesantren Al - Barkah harus membenahi struktur laporan keuangannya sesuai dengan ketentuan syariah dan PSAK 101, guna pertanggungjawaban kepada nasabah dan Allah SWT. Padahal sebagai entitas syariah harusnya berpedoman pada PSAK 101 dalam penyajian laporan keuangannya. Semua laporan yang tertuang pada PSAK 101 nantinya akan bermanfaat untuk pihak koperasi pondok pesantren Al- Barkah sendiri dan pihak- pihak lain yang terkait seperti investor, pemilik dana titipan, karyawan, pemerintah, masyarakat, dsb (Prasetyo, 2019).

\section{Pembahasan}

\section{Analisis terhadap laporan posisi keuangan}

Penyajian neraca atau neraca Lembaga Syariah memiliki persyaratan minimum yang meliputi: kas dan setara kas, piutang usaha beserta piutang lainnya, persediaan, investasi dengan metode ekuitas, aset keuangan, total aset, properti'investasi, aset tetap, aset tidak berwujud, kewajiban usaha maupun terutang lainnya, kewajiban keuangan, liabilitas dan aset untuk pajak kini, liabilitas dan aset pajak tangguhan, kewajiban yang termasuk didalam kelompok lepasan milik untuk dijual, provisi, kepentingan non pengendali, serta modal saham dan cadangan yang diatribusikan kepada pemilik entitas induk (Ikatan Akuntan Indonesia, 2009).

Unsur- Unsur komponen dan isi dalam laporan posisi keuangan Kopontren Al- Barkah yakni (Kopontren Al- Barkah, 2020): 
a. Pada pos aktiva lancar berisi kas, bank, deposito berjangka, piutang segera diterima, piutang anggota, piutang calon anggota, penyusutan piutang tak tertagih dan persediaan barang dagang

b. Aktiva tetap yang terdiri dari aktiva tetap serta akumulasi penyusutan aktiva tetap

c. Bagian Passiva

Pada bagian ini, terdapat pos- pos antara lain: kewajiban berjangka yang terdiri dari simpanan sukarela, hutang simpanan khusus, hutang segera dibayar, hutang dana sosial, hutang dana pendidikan, hutang bagi hasil anggota, hutang bagi hasil calon, dan hutang lain-lain

d. Hutang berjangka terdiri dari hutang bank

e. Modal yang terdiri dari dana cadangan, simpanan pokok, simpanan wajib, penyertaan modal, kemudian SHU yang dibagi menjadi SHU tahun lalu dan SHU tahun berjalan.

Laporan posisi keuangan Koperasi Pondok Pesantren Al- Barkah disusun dalam bentuk skontro yang disajikan dalam dua sisi yaitu passiva disisi kanan dan aktiva disisi kiri. Aset dalam Koperasi Pondok Pesantren Al- Barkah disajikan dengan nama aktiva, cadangan kerugian piutang dicatat dengan nama akun penyisihan piutang tak tertagih. Aktiva tetap tidak dijelaskan secara rinci namun hanya terdiri dari aktiva tetap dan akumulasi penyusutan aktiva tetap. Pada akun aktiva lainlain di neraca bernominal nol. Liabilitas (kewajiban hutang yang harus dibayarkan) Koperasi Pondok Pesantren Al- Barkah disajikan dengan nama akun kewajiban. Ekuitas terdiri dari simpanan pokok, simpanan wajib, dana cadangan, penyertaan modal, SHU yang dibagi menjadi SHU tahun lalu, dan SHU tahun berjalan (Kopontren Al- Barkah, 2020).

Mengacu pada hasil analisis penulis terhadap laporan keuangan yang tersaji pada dokumen Koperasi Pondok Pesanten Al- Barkah diketahui bahwa Koperasi Pondok Pesantren Al- Barkah menyajikan Laporan Posisi Keuangan. Namun dalam penyajiannya masih belum ditemukan kesesuaian dengan PSAK 101 dikarenakan hal- hal berikut yaitu:

1. Dana syirkah temporer yang tidak tersaji pada laporan posisi keuangan Koperasi Pondok Pesantren Al- Barkah.

2. Terdapat ketidaksesuaian aspek dalam laporan posisi keuangan Koperasi Pondok pesanten AlBarkah. Merujuk pada PSAK 101 aspek laporan posisi keuangan pada institusi syariah mencakup pos- pos yakni: aset, liabilitas, dana syirkah temporer serta ekuitas. Sedangkan laporan posisi keuangan Koperasi Pondok Pesantren Al- Barkah hanya menyajikan unsur yang terdiri dari aset, liabilitas dan ekuitas.

\section{Analisis terhadap Laporan Laba rugi}

Laporan kedua yang dibuat oleh Kopontren Al- barkah yaitu Laporan Laba Rugi. Laporan ini sedikitnya memiliki cakupan komponen antara lain sebagai berikut: pendapatan usaha, bagian laba rugi dari entitas asosiasi serta ventura bersama dan dicatat dengan metode ekuitas, bagi hasil untuk 
pemilik dana, beban pajak, dan jumlah tunggal untuk operasi yang dihentikan (Ikatan Akuntan Indonesia, 2009).

Sedangkan Laporan laba rugi yang disajikan oleh Koperasi Pondok Pesantren Al Barkah terdiri pendapatan dari pembiayaan. Kemudian biaya atau beban kerja yang terdiri dari bagi hasil simpanan, gaji, ATK, belanja inventaris,beban penyusutan, dan biaya lain- lain. Juga disajikan mengenai laba setelah pajak, biaya RAT dan SHU dibagikan (Kopontren Al- Barkah, 2020). Laporan laba rugi yang disajikan oleh Koperasi Pondok Pesantren Al- Barkah, berdasarkan temuan penulis, tidak sesuai dengan PSAK 101 karena tidak merinci pembagian pendapatan dan keuntungan kepada pemilik dana, sehingga dapat disimpulkan jika diukur terhadap dua jenis laporan keuangan tahunan yang disajikan, yaitu neraca dan laporan laba rugi, hal ini tentu saja tidak memenuhi standar akuntansi untuk penyajian laporan keuangan berdasarkan PSAK 101 yang harusnya terdiri atas 1) Laporan laba rugi, 2) Neraca, 3) Laporan arus kas, 4) Melaporkan sumber dan penggunaan kebajikan. 5) Laporan sumber dan penggunaan dana Zakat. Dan terakhir 7) catatan atas laporan keuangan (Ikatan Akuntan Indonesia, 2009).

Terdapat beberapa penelitian yang menunjukkan kesamaan, berdasarkan penelitianpenelitian sebelumnya yang dijadikan acuan. Artinya, penelitian PSAK 101, metode penelitian yang digunakan, dan teknik pengolahan data adalah sama. Penelitian sebelumnya menunjukkan bahwa perusahaan belum sepenuhnya menerapkan PSAK 101. Penelitian ini dilakukan oleh Amrul Ikhsan dan Musfiari Haridhi (2017), dengan judul "Implementasi Standar Akuntansi Keuangan Syariah Pada Koperasi Jasa Keuangan Syariah (Studi tentang baitul qiradh di kota). BQ Banda Aceh belum menerapkan PSAK 101 secara keseluruhan karena sumber daya manusia yang belum mengikuti ketentuan yang berlaku(Ikhsan \& Haridhi, 2017). Penelitian lanjutan oleh Naurah Nadzifah (2020) dengan judul "Analisis Penerapan PSAK 101 dalam Laporan Keuangan KSPPS BMT Al Bina Tasikmalaya”. Laporan keuangan tahunan yang disajikan oleh BMT Al Bina tidak sesuai dengan PSAK 101 karena beberapa faktor, seperti BMT Al Bina, tidak sepenuhnya memahami penyajian laporan keuangan tahunan PSAK 101 serta menurut pihaknya laporan yang dibuat sudah mencukupi kebutuhan (Nazhifah et al., 2020) . Penelitian lain yang berjudul "Akuntabilitas BMT: Analisis Berdasarkan Penerapan PSAK 101 Dalam Penyajian Laporan Keuangan" dilakukan oleh Putriningtyas (2019). Didapat hasil bahwa BMT Wanita Mandiri tidak menyajikan semua aspek sesuai dengan standar akuntansi syariah PSAK 101, karena didasarkan pada penyajian laporan keuangan tahunan sesuai dengan standar Kementerian Koperasi yang ada (Putriningtyas, 2019). Penelitian yang selaras dengan penelitian ini kebanyakan ditemukan dengan hasil tidak memenuhi standar PSAK 101 dikarenakan banyak faktor yaitu dari faktor internal dan eksternal entitas itu sendiri seperti kurang mahirnya tenaga akuntan dalam memahami akuntansi syariah, atau pemahaman mengenai penyajian laporan keuangan untuk institusi atau lembaga syariah yang masih kurang. 
Seperti yang telah disampaikan sebelumnya, bahwa aliran dana yang terjadi pada lembaga keuangan, khususnya lembaga syariah sangatlah penting. Tujuan dan landasan pada PSAK 101 diharapkan mampu mengarahkan penyusunan standar akuntansi dan pelaporan keuangan yang konsisten serta memiliki arah, fungsi, dan batasan yang jelas. Dewan Standar Akuntansi Keuangan dalam merumuskan Standar Akuntansi Keuangan, yang dimana hal ini akan berkaitan kembali dengan laporan - laporan keuangan yang harus dijelaskan dan disajikan secara detail kepada nasabah, dan pihak - pihak yang terkait dengan lembaga keuangan khususnya lembaga keuangan syariah tersebut. Ketidaksesuaian laporan keuangan dengan pedoman PSAK 101 dapat mengakibatkan pengambilan keputusan yang salah dikemudian hari, memberikan citra buruk bagi perusahaan, serta kemungkinan kecurangan yang dapat terjadi.

\section{KESIMPULAN DAN SARAN}

\section{Kesimpulan}

Dari deskripsi pada bagian pembahasan maka dalam penerapan Pernyataan Standar Akuntansi Keuangan No. 101 yang dilakukan di Koperasi Pondok Pesantren Al Barkah diperoleh hasil bahwa belum sesuai dengan PSAK 101 karena pada penyajian laporan keuangan baru terdapat 2 laporan yaitu laporan posisi keuangan dan laporan laba rugi seharusnya terdapat 7 laporan keuangan yang harus disajikan oleh entitas syariah .Selain itu, kedua laporan keuangan yang telah disajikan oleh Koperasi Pondok pesantren Al- Barkah belum memenuhi komponen penyajian sesuai yang tertuang pada PSAK 101. Terdapat beberapa perbedaan mengenai penulisan nama akun, pada laporan posisi keuangan tidak terdapat dana syirkah temporer, tidak adanya bagi hasil pemilik dana serta belum terperincinya pembuatan laporan laba rugi. Penyebab hanya disajikan 2 laporan keuangan oleh Koperasi Pondok Pesantren Al- Barkah yaitu karena menurut pihaknya hanya membutuhkan 2 jenis laporan keuangan yaitu laporan posisi keuangan dan laporan laba rugi. 2 laporan yang telah disajikan dianggap sudah memenuhi kebutuhan informasi pada Kopontren Al- Barkah.

\section{Saran}

Menurut pembahasan serta kesimpulan yang sudah diuraikan sebelumnya, maka saran yang penulis bisa berikan yaitu:

1. Bagi Pihak Lembaga

Kesesuaian penyajian laporan keuangan dengan pedoman PSAK 101 akan memberikan kemudahan dalam penyampaian informasi perusahan pada pihak internal dan eksternal. Selain itu kesesuaian penyajian laporan keuangan dapat meminimalisir tingkat kecurangan dalam pembuatan laporan keuangan sebabnya diperlukan peningkatan kualitas tenaga akuntan serta pemahaman dalam penyajian laporan keuangan agar laporan keuangan bisa tersaji dengan baik sesuai dengan PSAK 101 sebagai entitas yang menganut sistem syariah dalam setiap kegiatan dan 
transaksinya. Untuk memudahkan tenaga akuntan untuk menyusun laporan keuangan, dapat digunakan software accounting misalnya Smartcoop. Selain itu, format laporan keuangan yang dibuat sebaiknya merujuk pada standar PSAK 101. Penelitian ini dapat dijadikan evaluasi bagi pihak internal Koperasi Pondok pesantren Al- Barkah khususnya akuntan dalam penyajian laporan keuangan, serta laporan keuangan yang sudah ada diperbaiki dengan menggolongkan nama akun secara lebih terperinci agar informasi keuangan dapat tersampaikan dengan baik.

2. Bagi peneliti selanjutnya

Kedepannya, diharapkan untuk para peneliti selanjutnya untuk bisa meneliti aspek- aspek lain dari laporan keuangan ataupun penerapan terhadap SAK yang lain. Selain itu juga dapat dilakukan penelitian untuk membandingkan dengan entitas syariah yang lain.

\section{DAFTAR REFERENSI}

Aedy, H. (2007). Indabnya Ekonomi Islam. Alfabeta.

Ali, M. (2014). Memahami Riset dan Sosial. Bumi Aksara.

Asmitha. (2011). Analisis Perlakuan Akuntansi pembiayaan Gadai Syariah PT. Pengadaian Syariab. Universitas Hasanuddin.

Desita, D. (2006). Peranan Standar Akuntansi Syariah dalam Pengelolaan Transaksi Keuangan pada Bank Syariah. Jumal Ekonomi Dan Perbankan. https//repository.Widyatama.ac.id

Dewan Standar Akuntansi Syariah - IAI. (2016). PSAK 101 Tentang Penyajian Laporan Keuangan Syariah. Standar Akuntansi Keuangan Syariah, 1, 101.41.

Ikatan Akuntan Indonesia. (2009). PS AK Syariah No. 101: Penyajian Laporan Keuangan Syariah (Cetakan $\mathrm{Ke})$. Dewan Standar Akuntansi Keuangan.

Ikhsan, A., \& Haridhi, M. (2017). Penerapan standar akuntansi keuangan Syariah pada koperasi jasa keuangan Syariah (studi pada baitul qiradh di kota Banda Aceh). Jurnal Ilmiah Mahasiswa Ekonomi Akuntansi, 2(3), 100-110. https://www.neliti.com/publications/202132/penerapan-standarakuntansi-keuangan-syariah-pada-koperasi-jasa-keuangan-syariah

Kopontren Al- Barkah. (2020). Pedoman RAT Kopontren Al-Barkah.

Kusumawati, Z. (2005). Mengbitung Laba Perusabaan: Aplikasi Akuntansi Syariah (Cetakan I). Magistra Insani Press.

Muljono, D. (2015). Buku Pintar Akuntansi Perbankan dan Lembaga Kenangan Syariah. Penerbit Andi.

Nazhifah, N., Wisandani, I., \& Marlina, L. (2020). Analisis Implementasi Psak 101 Pada Laporan Keuangan Di Kspps Bmt Al-Bina Tasikmalaya. Jurnal Ekonomi Syariah, 5(1), 42-58. http://jurnal.unsil.ac.id/index.php/jes/article/view/1577

Nurhayati, S., \& Wasilah. (2019). Akuntansi Syariah di Indonesia. Salemba Empat.

Prasetyo, A. (2019). Akuntansi Keuangan Syariah: Teori, Kasus, dan Pengantar Menuju Praktik (M. Kika (ed.); 1st ed.). Penerbit Andi.

Putriningtyas, U. (2019). Akuntabilitas BMT: Analisis Berdasarkan Implementasi PSAK 101 Pada Penyajian Laporan Keuangan. Jurnal Ekonomi Dan Keislaman, 7, 17-36.

Sri Nurhayati, W. (2011). Akuntansi Syariah di Indonesia. Salemba Empat.

Sugiyono. (2016). Metode Penelitian Kuantitatif Kualitatif dan R \& D. Alfabeta. 